\title{
Actinokineospora soli sp. nov., a thermotolerant actinomycete isolated from soil, and emended description of the genus Actinokineospora
}

Correspondence
Wen-Jun Li
wjli@ynu.edu.cn
Shu-Kun Tang
tangshukun@hotmail.com
†These authors contributed equally to this work.

The GenBank/EMBL/DDBJ accession number for the 16S rRNA gene sequence of strain YIM $75948^{\top}$ is JN005785.

A supplementary table and three supplementary figures are available with the online version of this paper.
In 1988, the genus Actinokineospora was proposed by Hasegawa, with Actinokineospora riparia NRRL B-16432 ${ }^{\mathrm{T}}$ as the type strain of the type species (Hasegawa, 1988a, b). Subsequently, Labeda et al. (2010) proposed not only an emended description of the genus, to accommodate those Actinokineospora species that are unable to produce motile spores, but also the transfer of Amycolatopsis fastidiosa to 
the genus (as Actinokineospora fastidiosa comb. nov.). At the time of writing, there are 11 species in the genus: Actinokineospora riparia, Actinokineospora inagensis, Actinokineospora globicatena, Actinokineospora terrae, Actinokineospora diospyrosa, Actinokineospora auranticolor, Actinokineospora enzanensis, Actinokineospora fastidiosa, Actinokineospora baliensis, Actinokineospora cibodasensis and Actinokineospora cianjurensis (Hasegawa, 1988a; Tamura et al., 1995; Otoguro et al., 2001; Labeda et al., 2010; Lisdiyanti et al., 2010).

During a project to isolate rare actinobacterial strains from soil samples in the Chinese province of Yunnan, an actinomycete was isolated that displayed moderate growth at $50{ }^{\circ} \mathrm{C}$ on International Streptomyces Project (ISP) medium 2 (Shirling \& Gottlieb, 1966). The taxonomic affiliations of this isolate, which was designated strain YIM $75948^{\mathrm{T}}$, were investigated using a polyphasic approach. In a phylogenetic analysis based on 16S rRNA gene sequences, the novel strain was found to be closely related to Actinokineospora fastidiosa DSM $43855^{\mathrm{T}}$. However, these two strains differed sufficiently in several characteristics for strain YIM $75948^{\mathrm{T}}$ to be considered a novel species in the genus Actinokineospora.

Strain YIM $75948^{\mathrm{T}}$ was isolated by plating dilutions from a soil sample collected in Yunnan province on ISP 2 agar. The pure culture was preserved in $20 \%(\mathrm{v} / \mathrm{v})$ glycerol at $-80{ }^{\circ} \mathrm{C}$. Once it became clear that, in terms of its $16 \mathrm{~S}$ rRNA gene sequence, A. fastidiosa DSM $43855^{\mathrm{T}}$ was the recognized species most closely related to the new strain (see below), the morphological, physiological, biochemical and chemotaxonomic characteristics of strain YIM $75948^{\mathrm{T}}$ were carefully compared with those of $A$. fastidiosa DSM $43855^{\mathrm{T}}$. The latter strain was obtained from the Deutsche Sammlung von Mikroorganismen und Zellkulturen at Braunschweig, Germany. The two strains were routinely cultivated on Czapek's agar or ISP media at $37{ }^{\circ} \mathrm{C}$ (Shirling \& Gottlieb, 1966). The colours of the substrate and aerial mycelia and any soluble pigments produced were determined by comparison with chips from the ISCC-NBS colour charts (Kelly, 1964). Unless otherwise indicated, the phenotypic characteristics were studied using standard procedures (Smibert \& Krieg, 1994; Tang et al., 2011). Antibiotic susceptibility was examined by using antibiotic discs on Czapek's agar, as described by Williams et al. (1989). The cell morphology of strain YIM $75948^{\mathrm{T}}$ was observed under a light microscope (model BH2; Olympus) and in a scanning electron microscope (JSM5600LV; JEOL) after incubation for 28 days at $37{ }^{\circ} \mathrm{C}$ on ISP 2 agar. Electron microscopy was performed as described by Nedashkovskaya et al. (2005).

Genomic DNA was extracted and prepared for $16 \mathrm{~S}$ rRNA gene amplification, the determination of $\mathrm{G}+\mathrm{C}$ content and DNA-DNA hybridization tests using the method described by Marmur (1961). PCR amplification of the 16S rRNA gene sequence was performed as described by $\mathrm{Li}$ et al. (2007). The 16S rRNA gene sequence was manually aligned with reference sequences retrieved from the GenBank database following BLAST searches. Phylogenetic trees were constructed using version 4.0 of the MEGA software package (Tamura et al., 2007) after multiple alignments of the sequences with CLUSTAL_X (Thompson et al., 1997). Corrected evolutionary distances were calculated according to Kimura's two-parameter model (Kimura, 1980, 1983) and phylogenetic trees were constructed using the neighbourjoining and maximum-parsimony algorithms. Tree topologies were evaluated by bootstrap analysis with 1000 resamplings (Felsenstein, 1985).

Genomic DNA G + C content was determined by reversephase HPLC according to Mesbah et al. (1989). DNA-DNA hybridizations were performed by the fluorometric method, in microdilution wells with photobiotin, as described by Ezaki et al. (1989). Such hybridizations were performed between strain YIM $75948^{\mathrm{T}}$ and A. fastidiosa DSM $43855^{\mathrm{T}}$ with eight replicates. The bacterial biomass used for the chemotaxonomic analyses (of amino acids, whole-cell sugars, fatty acids, respiratory quinones and polar lipids) was produced by incubation in ISP 2 broth at $37^{\circ} \mathrm{C}$ for 3 days. Respiratory quinones were extracted from lyophilized cells and the extracts were purified and analysed by HPLC, using the procedures reported by $\mathrm{Hu}$ et al. (2001). The procedures used for the identification of whole-cell sugars were those described by Tang et al. (2009a). The isomer of diaminopimelic acid in the cell walls was analysed according to the procedures developed by Hasegawa et al. (1983). The amino acids in peptidoglycan hydrolysates were analysed by HPLC after precolumn derivatization with o-phthalaldehyde (Tang et al., 2009b). Cellular fatty acids were investigated as described by Sasser (1990), using version 6.1 of the Sherlock Microbial Identification System (MIDI) and the TSBA6 database. Polar lipids were extracted, separated by two-dimensional TLC and identified by following the procedures of Minnikin et al. (1984).

Strain YIM $75948^{\mathrm{T}}$ showed good growth on Czapek's agar, inorganic salts/starch (ISP 4) agar and nutrient agar; moderate growth was observed on ISP 2, oatmeal (ISP 3), glycerol/asparagine (ISP 5) and potato dextrose (PD) agars. Aerial mycelium was produced on Czapek's, ISP 2 and nutrient agars but not on PD, ISP 3, ISP 4 or ISP 5 agar. Motile spores were never observed on any of the media. Both the aerial and substrate mycelia were white to pale yellow in colour (or, occasionally, pale pink) and rodshaped spores with smooth surfaces were produced (Fig. S1, available in IJSEM Online). Soluble pigments were not produced. Strain YIM $75948^{\mathrm{T}}$ grew at $25-55{ }^{\circ} \mathrm{C}$ (optimum $37{ }^{\circ} \mathrm{C}$ ), at $\mathrm{pH} 7.0-9.0$ (optimum $\mathrm{pH} 8.0$ ) and with $0-5 \%$ (w/v) $\mathrm{NaCl}$ (optimum between $0 \%$ and $2 \%$ ). The phenotypic properties that can be used to distinguish strain YIM $75948^{\mathrm{T}}$ from A. fastidiosa DSM $43855^{\mathrm{T}}$ are shown in Table 1. The main characteristics of strain YIM $75948^{\mathrm{T}}$ are summarized in the species description.

In phylogenetic analyses based on the almost-complete 16S rRNA gene sequence of strain YIM $75948^{\mathrm{T}}$ and the corresponding sequences of closely related species, strain 
Table 1. Morphological and physiological characteristics that distinguish strain YIM $75948^{\top}$ from A. fastidiosa DSM $43855^{\top}$

Strains: 1, YIM $75948^{\mathrm{T}} ; 2$, A. fastidiosa DSM $43855^{\mathrm{T}}$. All data from this study. Both strains showed optimum growth at $37{ }^{\circ} \mathrm{C}$ and were negative for oxidase and tryptophan deaminase activities but positive for catalase activity. Both hydrolysed gelatin, starch and Tween 20 but not cellulose, gave a positive result in the methyl red test but did not produce $\mathrm{H}_{2} \mathrm{~S}$. Both utilized cellobiose and D-glucose as sole carbon sources, but not L-arabinose, dulcitol, glycerol, inositol, lactose, raffinose, L-rhamnose, sodium citrate, sodium oxalate, starch or trehalose. Both utilized L-alanine, L-arginine, glycine, D-histidine, Lhydroxyproline, hypoxanthine, D-phenylalanine, L-lysine, D-proline, L-tyrosine, D-threonine, D-valine and xanthine (but not glutamic acid) as sole nitrogen sources. +, Positive; -, negative; $\mathrm{S}$, sensitive; $\mathrm{R}$, resistant

\begin{tabular}{|c|c|c|}
\hline Characteristic & 1 & 2 \\
\hline Colony reverse colour & Yellow-white & Pale yellow-yellow \\
\hline $\begin{array}{l}\text { Colour of aerial } \\
\text { mycelium }\end{array}$ & Yellow-white & White-pale pink \\
\hline Optimum pH & 8 & $7-8$ \\
\hline Growth at $55{ }^{\circ} \mathrm{C}$ & + & - \\
\hline Urease & - & + \\
\hline Nitrate reduction & - & + \\
\hline \multicolumn{3}{|l|}{ Lipase tests } \\
\hline Tween 40 & + & - \\
\hline Tween 60 & - & + \\
\hline Tween 80 & - & + \\
\hline \multicolumn{3}{|l|}{ Carbohydrate utilization } \\
\hline Mannitol & + & - \\
\hline D-Mannose & + & - \\
\hline Maltose & + & - \\
\hline D-Xylose & - & + \\
\hline D-Fructose & - & + \\
\hline D-Galactose & + & - \\
\hline Sucrose & + & - \\
\hline Xylitol & + & - \\
\hline \multicolumn{3}{|l|}{ Nitrogen utilization } \\
\hline L-Serine & - & + \\
\hline L-Aspartic acid & - & + \\
\hline \multicolumn{3}{|l|}{ Antibiotic susceptibility } \\
\hline Clindamycin & s & $\mathrm{R}$ \\
\hline Penicillin & s & $\mathrm{R}$ \\
\hline Erythromycin & s & $\mathrm{R}$ \\
\hline Amikacin & $\mathrm{R}$ & S \\
\hline Tetracycline & $\mathrm{R}$ & s \\
\hline
\end{tabular}

YIM $75948^{\mathrm{T}}$ appeared to belong in the genus Actinokineospora and was clustered with $A$. fastidiosa DSM $43855^{\mathrm{T}}$ in a deep branch of each of the phylogenetic trees (Figs 1 and S2). Since the level of $16 \mathrm{~S}$ rRNA gene sequence similarity between strain YIM $75948^{\mathrm{T}}$ and A. fastidiosa DSM $43855^{\mathrm{T}}$ was fairly high $(97.6 \%)$, DNA-DNA hybridizations between these two strains were indicated (Stackebrandt \& Goebel, 1994). The mean level of DNA-DNA relatedness between strain YIM $75948^{\mathrm{T}}$ and A. fastidiosa DSM $43855^{\mathrm{T}}$ was, however, only $47.8 \pm 4.2 \%$, a value that falls well below the threshold value, of $70 \%$, that, when exceeded, is taken to indicate that the hybridized strains probably belong to the same species (Stackebrandt \& Goebel, 1994).

The genomic DNA G + C content of strain YIM $75948^{\mathrm{T}}$ was $73.8 \mathrm{~mol} \%$ and its major fatty acids were iso- $\mathrm{C}_{15: 0}(15.9 \%)$, iso- $\mathrm{C}_{16: 0}(37.4 \%)$ and $\mathrm{C}_{16: 0}(12.2 \%)$. Under the same incubation and analysis conditions, the genomic DNA G $+\mathrm{C}$ content of $A$. fastidiosa DSM $43855^{\mathrm{T}}$ was $73.5 \mathrm{~mol} \%$ and its major fatty acids were iso- $\mathrm{C}_{15: 0}(14.2 \%)$, iso- $\mathrm{C}_{16: 0}(41.1 \%)$, $\mathrm{C}_{16: 0}(10.1 \%)$ and $\mathrm{C}_{17: 1} \omega 6 \mathrm{C}(11.3 \%)$. The detailed fatty acid profiles of the novel strain and A. fastidiosa DSM $43855^{\mathrm{T}}$ are displayed in Table S1. The predominant respiratory quinone of strain YIM $75948^{\mathrm{T}}$ was MK-9 $\left(\mathrm{H}_{4}\right)$ (91.7\%) but MK-9 $\left(\mathrm{H}_{6}\right)(4.0 \%)$, MK-9 (2.2\%) and MK$9\left(\mathrm{H}_{8}\right)(2.1 \%)$ were detected as minor components. The polar lipid profile of strain YIM $75948^{\mathrm{T}}$ was similar to that of A. fastidiosa DSM $43855^{\mathrm{T}}$, consisting of phosphatidylethanolamine, phosphatidylethanolamine with hydroxy fatty acids, diphosphatidylglycerol, phosphatidylinositol and, as minor components, two unidentified phospholipids (Fig. S3). For both strain YIM $75948^{\mathrm{T}}$ and A. fastidiosa DSM $43855^{\mathrm{T}}$, meso-diaminopimelic acid was identified as the cellwall diamino acid, glycine, glutamic acid, alanine and aspartic acid were found to be the main amino acids of the peptidoglycan, and the whole-cell sugars were identified as mannose, ribose, glucose, galactose and arabinose.

Although the phylogenetic analysis and chemotaxonomic characteristics (major fatty acids, polar lipids, cell-wall diamino acid and respiratory quinones) supported the assignment of strain YIM $75948^{\mathrm{T}}$ to the genus Actinokineospora, certain physiological and biochemical characteristics of the novel strain (growth at $55{ }^{\circ} \mathrm{C}$, nitrate reduction, urease and lipase activities and utilization of particular carbohydrates and nitrogen sources) distinguished it from all recognized species of the genus Actinokineospora. Furthermore, the fatty acid content of strain YIM $75948^{\mathrm{T}}$ was fairly distinct from that of A. fastidiosa DSM $43855^{\mathrm{T}}$ (Table S1). Based on the results of the morphological, physiological and chemotaxonomical characterizations and DNA-DNA hybridizations, strain YIM $75948^{\mathrm{T}}$ represents a novel species of the genus Actinokineospora for which the name Actinokineospora soli sp. nov. is proposed.

\section{Emended description of the genus Actinokineospora}

The description is as given for the genus Actinokineospora by Labeda et al. (2010) with the following addition. The range of genomic DNA $\mathrm{G}+\mathrm{C}$ contents, as determined by HPLC, is $69-74 \mathrm{~mol} \%$.

\section{Description of Actinokineospora soli sp. nov.}

Actinokineospora soli (so'li. L. neut. gen. n. soli of soil, the source of the type strain).

Cells are Gram-staining-positive, aerobic and thermotolerant. The mycelium, which is white to pale yellow (or, 


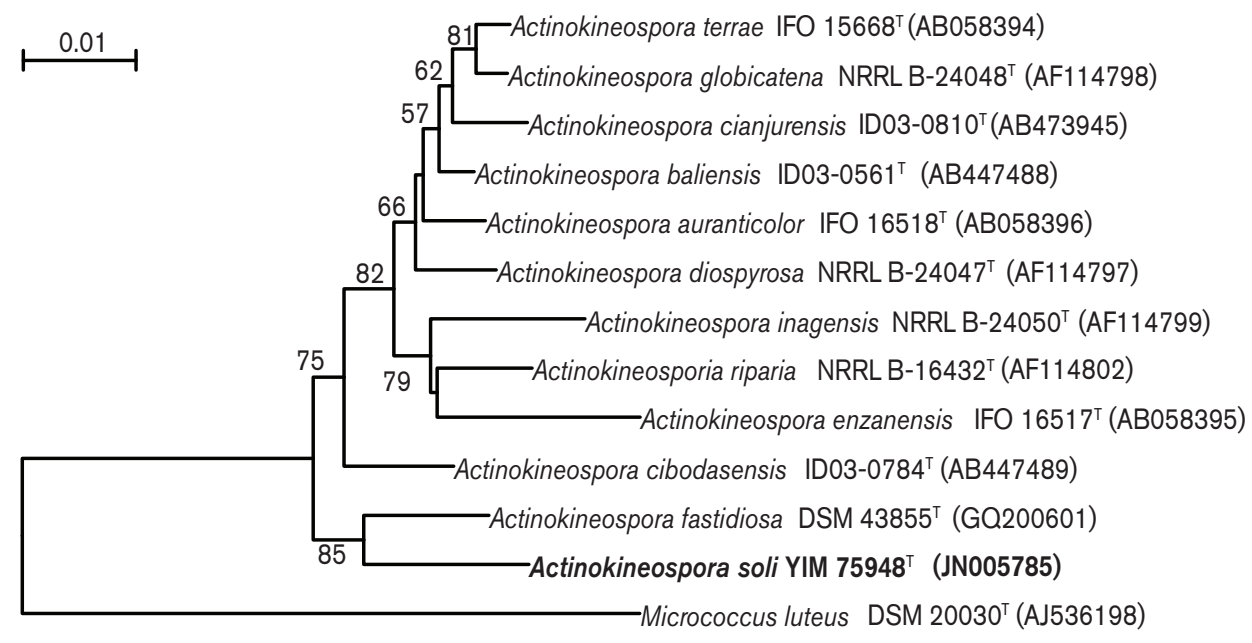

Fig. 1. Neighbour-joining phylogenetic tree based on $16 \mathrm{~S}$ rRNA gene sequences, showing the position of strain $\mathrm{YIM}^{7} 75948^{\top}$ in relation to members of the genus Actinokineospora. Bootstrap values $>50 \%$, based on 1000 replications, are shown at branching points. Bar, 0.01 substitutions per nucleotide position.

occasionally, pale pink), produces rod-shaped, smooth, non-motile spores. Soluble pigments are not produced. Growth occurs at $25-55{ }^{\circ} \mathrm{C}$ (optimum $37^{\circ} \mathrm{C}$ ), at $\mathrm{pH} 7.0$ 9.0 (optimum $\mathrm{pH} 8.0$ ) and with $0-5 \%$ (w/v) $\mathrm{NaCl}$ (optimum between $0 \%$ and $2 \%$ ). Positive for catalase activity but negative for oxidase, urease and tryptophan deaminase activities. Hydrolyses starch, gelatin and Tweens 20 and 40, but not cellulose or Tweens 60 or 80 . Nitrate is not reduced to nitrite. Negative result in the VogesProskauer test but positive result in the methyl red test. $\mathrm{H}_{2} \mathrm{~S}$ is not produced. As sole carbon sources, cellobiose, Dgalactose, D-glucose, mannitol, D-mannose, maltose, sucrose and xylitol are utilized, but not L-arabinose, dulcitol, glycerol, inositol, lactose, raffinose, L-rhamnose, sodium citrate, sodium oxalate, starch, trehalose or D-xylose. As sole nitrogen sources, L-alanine, L-arginine, glycine, Dhistidine, L-hydroxyproline, hypoxanthine, D-phenylalanine, L-lysine, D-proline, L-tyrosine, D-threonine, D-valine and xanthine are utilized, but not glutamic acid, L-serine or L-aspartic acid. Acid is produced from cellobiose, dulcitol, D-galactose, D-glucose, mannitol, D-mannose, sucrose and xylitol, but not from L-arabinose, D-fructose, glycerol, inositol, lactose, maltose, raffinose, L-rhamnose, sodium citrate, sodium oxalate, trehalose, D-xylose or starch. The type strain is susceptible to chloramphenicol $(30 \mu \mathrm{g})$, ciprofloxacin $(5 \mu \mathrm{g})$, clindamycin $(2 \mu \mathrm{g})$, erythromycin $(15 \mu \mathrm{g})$, gentamicin $(10 \mu \mathrm{g})$, penicillin $(10 \mu \mathrm{g})$, netilmicin $(30 \mu \mathrm{g})$, novobiocin $(5 \mu \mathrm{g})$, rifampicin $(5 \mu \mathrm{g})$, tobramycin $(10 \mu \mathrm{g})$ and vancomycin $(30 \mu \mathrm{g})$, but resistant to ampicillin $(10 \mu \mathrm{g})$, amikacin $(30 \mu \mathrm{g})$, norfloxacin $(10 \mu \mathrm{g})$, tetracycline $(30 \mu \mathrm{g})$ and trimethoprim $(1.25 \mu \mathrm{g})$. Cell hydrolysates contain meso-diaminopimelic acid as the diagnostic cell-wall diamino acid, and glycine, glutamic acid, alanine and aspartic acid are the main amino acids in the peptidoglycan. Extracts of whole-cell sugars contain mannose, ribose, glucose, galactose and arabinose. The polar lipids consist of phosphatidylethanolamine, phosphatidylethanolamine with hydroxy fatty acids, diphosphatidylglycerol, phosphatidylinositol and two unidentified phospholipids. The major fatty acids are iso- $\mathrm{C}_{15: 0}$, iso- $\mathrm{C}_{16: 0}$ and $\mathrm{C}_{16: 0}$.

The type strain, YIM $75948^{\mathrm{T}}\left(=\mathrm{JCM} 17695^{\mathrm{T}}=\mathrm{DSM} 45613^{\mathrm{T}}\right)$, was isolated from a soil sample collected in Yunnan province, China. The genomic DNA G $+\mathrm{C}$ content of the type strain is $73.8 \mathrm{~mol} \%$.

\section{Acknowledgements}

The authors are grateful to Professor Hans-Peter Klenk for kindly providing Actinokineospora fastidiosa DSM $43855^{\mathrm{T}}$. This work was supported by the National Basic Research Program of China (via grant 2010CB833801), the National Natural Science Foundation of China (31000001 and 31070007) and the China Postdoctoral Science Foundation (20090461410). W.-J.L. was also supported by the 'Hundred Talents Program' of the Cinese Academy of Sciences.

\section{References}

Ezaki, T., Hashimoto, Y. \& Yabuuchi, E. (1989). Fluorometric deoxyribonucleic acid-deoxyribonucleic acid hybridization in microdilution wells as an alternative to membrane filter hybridization in which radioisotopes are used to determine genetic relatedness among bacterial strains. Int J Syst Bacteriol 39, 224-229.

Felsenstein, J. (1985). Confidence limits on phylogenies: an approach using the bootstrap. Evolution 39, 783-791.

Hasegawa, T. (1988a). Actinokineospora: a new genus of the Actinomycetales. Actinomycetologica 2, 31-45.

Hasegawa, T. (1988b). Actinokineospora gen. nov. In Validation of the Publication of New Names and New Combinations Previously Effectively Published Outside the IJSB, List no. 27. Int J Syst Bacteriol 38, 449 . 
Hasegawa, T., Takizawa, M. \& Tanida, S. (1983). A rapid analysis for chemical grouping of aerobic actinomycetes. J Gen Appl Microbiol 29, 319-322.

Hu, H. Y., Lim, B. R., Goto, N. \& Fujie, K. (2001). Analytical precision and repeatability of respiratory quinones for quantitative study of microbial community structure in environmental samples. J Microbiol Methods 47, 17-24.

Kelly, K. L. (1964). Inter-Society Color Council-National Bureau of Standards Color-Name Charts Illustrated with Centroid Colors. Washington, DC: US Government Printing Office.

Kimura, M. (1980). A simple method for estimating evolutionary rates of base substitutions through comparative studies of nucleotide sequences. J Mol Evol 16, 111-120.

Kimura, M. (1983). The neutral theory of molecular evolution. Cambridge: Cambridge University Press.

Labeda, D. P., Price, N. P., Tan, G. Y. A., Goodfellow, M. \& Klenk, H.-P. (2010). Emended description of the genus Actinokineospora Hasegawa 1988 and transfer of Amycolatopsis fastidiosa Henssen et al. 1987 as Actinokineospora fastidiosa comb. nov. Int J Syst Evol Microbiol 60, 1444-1449.

Li, W. J., Xu, P., Schumann, P., Zhang, Y. Q., Pukall, R., Xu, L. H., Stackebrandt, E. \& Jiang, C. L. (2007). Georgenia ruanii sp. nov., a novel actinobacterium isolated from forest soil in Yunnan (China), and emended description of the genus Georgenia. Int J Syst Evol Microbiol 57, 1424-1428.

Lisdiyanti, P., Otoguro, M., Ratnakomala, S., Lestari, Y., Hastuti, R. D., Triana, E., Katsuhiko, A. \& Widyastuti, Y. (2010). Actinokineospora baliensis sp. nov., Actinokineospora cibodasensis sp. nov. and Actinokineospora cianjurensis sp. nov., isolated from soil and plant litter. Int $J$ Syst Evol Microbiol 60, 2331-2335.

Marmur, J. (1961). A procedure for the isolation of deoxyribonucleic acid from micro-organisms. J Mol Biol 3, 208-218.

Mesbah, M., Premachandran, U. \& Whitman, W. B. (1989). Precise measurement of the $\mathrm{G}+\mathrm{C}$ content of deoxyribonucleic acid by highperformance liquid chromatography. Int J Syst Bacteriol 39, 159-167.

Minnikin, D. E., O'Donnell, A. G., Goodfellow, M., Alderson, G., Athalye, M., Schaal, A. \& Parlett, J. H. (1984). An integrated procedure for the extraction of bacterial isoprenoid quinones and polar lipids. J Microbiol Methods 2, 233-241.

Nedashkovskaya, O. I., Kim, S. B., Suzuki, M., Shevchenko, L. S., Lee, M. S., Lee, K. H., Park, M. S., Frolova, G. M., Oh, H. W. \& other authors (2005). Pontibacter actiniarum gen. nov., sp. nov., a novel member of the phylum 'Bacteroidetes', and proposal of Reichenbachiella gen. nov. as a replacement for the illegitimate prokaryotic generic name Reichenbachia Nedashkovskaya et al. 2003. Int J Syst Evol Microbiol 55, 2583-2588.
Otoguro, M., Hayakawa, M., Yamazaki, T., Tamura, T., Hatano, K. \& limura, Y. (2001). Numerical phenetic and phylogenetic analysis of Actinokineospora isolates, with a description of Actinokineospora auranticolor sp. nov. and Actinokineospora enzanensis sp. nov. Actinomycetologica 15, 30-39.

Sasser, M. (1990). Identification of bacteria by gas chromatography of cellular fatty acids. USFCC Newsl 20, 16.

Shirling, E. B. \& Gottlieb, D. (1966). Methods for characterization of Streptomyces species. Int J Syst Bacteriol 16, 313-340.

Smibert, R. M. \& Krieg, N. R. (1994). Phenotypic characterization. In Methods for General and Molecular Bacteriology, pp. 607-654. Edited by P. Gerhardt, R. G. E. Murray, W. A. Wood \& N. R. Krieg. Washington, DC: American Society for Microbiology.

Stackebrandt, E. \& Goebel, B. M. (1994). Taxonomic note: a place for DNA-DNA reassociation and 16S rRNA sequence analysis in the present species definition in bacteriology. Int J Syst Bacteriol 44, 846849.

Tamura, T., Hayakawa, M., Nonomura, H., Yokota, A. \& Hatano, K. (1995). Four new species of the genus Actinokineospora: Actinokineospora inagensis sp. nov., Actinokineospora globicatena sp. nov., Actinokineospora terrae sp. nov. and Actinokineospora diospyrosa sp. nov. Int J Syst Bacteriol 45, 371-378.

Tamura, K., Dudley, J., Nei, M. \& Kumar, S. (2007). MEGA4: molecular evolutionary genetics analysis (MEGA) software version 4.0. Mol Biol Evol 24, 1596-1599.

Tang, S. K., Wang, Y., Chen, Y., Lou, K., Cao, L. L., Xu, L. H. \& Li, W. J. (2009a). Zhihengliuella alba sp. nov., and emended description of the genus Zhihengliuella. Int J Syst Evol Microbiol 59, 2025-2031.

Tang, S. K., Wang, Y., Lou, K., Mao, P. H., Xu, L. H., Jiang, C. L., Kim, C. J. \& Li, W. J. (2009b). Kocuria halotolerans sp. nov., an actinobacterium isolated from a saline soil in China. Int J Syst Evol Microbiol 59, 1316-1320.

Tang, S. K., Zhi, X. Y., Wang, Y., Shi, R., Lou, K., Xu, L. H. \& Li, W. J. (2011). Haloactinopolyspora alba gen. nov., sp. nov., a halophilic filamentous actinomycete isolated from a salt lake, with proposal of Jiangellaceae fam. nov. and Jiangellineae subord. nov. Int J Syst Evol Microbiol 61, 194-200.

Thompson, J. D., Gibson, T. J., Plewniak, F., Jeanmougin, F. \& Higgins, D. G. (1997). The CLUSTAL_X windows interface: flexible strategies for multiple sequence alignment aided by quality analysis tools. Nucleic Acids Res 25, 4876-4882.

Williams, S. T., Goodfellow, M. \& Alderson, G. (1989). Genus Streptomyces Waksman and Henrici 1943, 339AL. In Bergey's Manual of Systematic Bacteriology, vol. 4, pp. 2463-2468. Edited by S. T. Williams, M. E. Sharpe \& J. G. Holt. Baltimore: Williams \& Wilkins. 